\title{
The Integrative Approach to the Study \\ of the Social Mood Phenomenon \\ from the Standpoint of the Universum Sociology \\ (on the Example of the Social Mood \\ of Young People in Krasnoyarsk)
}

\author{
Olga V. Vasil'eva* \\ Siberian Federal University \\ 79 Svobodny, Krasnoyarsk, 660041, Russia
}

Received 07.09.2015, received in revised form 11.09.2015, accepted 29.10.2015

\begin{abstract}
From the standpoint of the universum sociology, the social mood is considered as multi-aspect characteristics of the social community that develops under the influence of social practices and determines the social behaviour of the representative of the given community. The phenomenon of the social mood is an integral developing dynamic system with the multi-level structure. The concepts of the social mood and social health are deeply correlated. The mass consciousness (unconsciousness) of the youth in the city of Krasnoyarsk is both optimistic and pessimistic. There are three main types of the social mood. The given socio-demographic group can be characterized by the main types of intentions.
\end{abstract}

Keywords: social mood, social health, youth, principle of minimum universum, optimism, pessimism, needs, focus on emotional sufferings.

DOI: 10.17516/1997-1370-2015-8-11-2248-2259.

Research area: sociology.

1. Introduction. Researchers of social processes have long paid attention to the special role of the social mood in the public consciousness and behaviour. This phenomenon has been studied for a long time within the framework of collective psychology and sociology of social consciousness (on, C. Cooley, G. Tarde, E. Durkheim, obertis et al.). Among the famous scholars of the social mood are ekhterev, oitolovsky, etrazhitsky, arygin, l'shansky, Zh.T. Toshchenko, harchenko and others. In our opinion, the specificity of the social mood is more completely reflected in the definition of Zh.T. Toshchenko and harchenko. They define the social mood as "a integrated form of perception of life, the dominant form of actual functioning of public consciousness and behaviour, reflecting the level, duration and degree of emotional and rational perception of social attitudes, social goals and interests by a person, social group and community, various

C) Siberian Federal University. All rights reserved

* Corresponding author E-mail address: yyoollyyaa@gmail.com 
organizations and institutions, formed under the influence of real economic, political and spiritual processes and potentially implemented (or not implemented) in practice" (Toshchenko \& Kharchenko, 1996).

The social mood is an integrating indicator of the level of well-being, social order and stability of the society. The importance of this phenomenon for social science is confirmed by techniques of measuring the dynamics of the social attitudes index (Levada Center) and social optimism index (VTsIOM) developed by sociological research organizations (Balatskii, 2005). Such techniques are designed to identify general indicators of the dynamics of mass society moods and to assess the impact of the mass consciousness on the development of the country and have an important quality: predictive capabilities.

On the one hand, the social mood is influenced by practice, on the basis of the system if values, on the other hand, has an impact on the human behaviour, social groups and society. In many ways, it is the latter that determines the urgency of the study of the social mood. In this sense, we cannot but agree with Zh.T. Toshchenko that in this case we do not discover a new object, we only "obtain new understanding of (...) the nature and values of the dominant of the public life anticipating the real, actual behaviour of people" (Toshchenko, 1998).

\section{Theoretical framework. Modern} sociology has valuable developments in the field the social mood and social health studies (in our opinion, it is inappropriate to equate these two concepts,). The social mood includes static and dynamic elements. If the first one is largely a manifestation of such characteristics of a subject or a group as social health and includes cognitive and emotional components, the second one is related to the activity, behavioural aspects and is expressed in the social attitude to certain actions. Social health that has been quite intensively studied in Russia in recent year, is not so clearly defined by researchers (Lepeshkin, 2004; Petrova, , 2004; Rusalinova, 1994; Khasbulatova \& Egorova, 2002; Nemirovsky, 2002). What remains unchangeable in all the interpretations is that social health is a subjective assessment, the result of how an individual or a social group understand their current position in a variety of its manifestations. Thus, the most appropriate seems to agree with ogozin and a number of Russian and foreign authors and accept the concept of social health identical to the concept of subjective wellbeing (Golovakha \& Panina, 2005; Rogozin, 2007; Rubina, 1996; Nemirovsky \& Nemirovskaia, 2015). Nevertheless, some papers dedicated to this issue do not provide clear distinction between the concepts of the social mood and social health (Sheregi \& Kharcheva, 1996; Zborovskii \& Shirokova, 2001), their substitution or equation can be observed, the latter, in our opinion, being more limited.

Some scientists (Kol'tsova V.A., Oleinik Iu.N., Simonovich N.E. et al.) rightly emphasize the presence of the behavioral component in social health (Orlov, 2000; Simonovich et al., 1999; Stepanova, 2013). But it is when we deal with the interpretation of social health, which is committed to a more holistic understanding of the phenomenon, and in this case, we speak rather about the social mood.

\section{Statement of the problem and methods}

of study. The problem of studying the social mood is that there is a need for a sociological model to reveal its qualities peculiar for a certain social or socio-demographic group. Today, sociology has approaches that provide new opportunities for the integrated study of the social mood. Thus, a common sociological model of explication of the main structural and dynamic properties of the social mood can be proposed using the postnonclassical (universum) sociological approach developed by emirovsky (Nemirovsky, 2004). 
This approach peculiar by its integral perception of the process of human socialization in the unity of its diverse manifestations, allows to review the minimum amount of characteristics necessary to describe the social mood of any social system. The principle of the minimum universum is a matrix, which is the basis for the development of any system. According to this principle, any developing system is based on two polar elements. In the process of changing, the system forms at least three hierarchical levels. Each level includes five stages the system goes through: birth, growth, change, fading and disappearance. The system forms at least seven layers, which reflect the sequence of its evolutionary development (Nemirovsky \& Starikov, 2003).

The results of the survey conducted in January and February of 2015 among the youth of Krasnoyarsk city (sample multitude was 400 people) allow us to conclude that the social mood of Krasnoyarsk students is a complex multi-level system. The analysis of the main questions of the questionnaire showed that the representatives of the sample multitude can be divided into two poles: "optimists" and "pessimists", the first of which are characterized by a typical positive assessment of the quality of the changes that occurred in their lives over the past year, positive expectations of the changes coming in the next year and the mood at the time of the survey close to good. We also observe conditional division in two groups with respect to independent criteria: on the one hand, into the "active" and "passive" with a slight predominance of the "active", and on the other hand, into the "settled" and "unsettled" with a slight predominance of the "settled". Thus, the more willing is the respondent to participate in different events and projects, the more active is the respondent, the better the respondent evaluates the situation in the main areas of his life, the more the respondent is settled.

Application of the factor and correlation analysis for processing the responses to the questionnaire allows us to establish that there are at least seven major sets, or intentions that comprise the social mood of the given sociodemographic group. The distribution of these sets is shown in Table 1.

The two complementary components of the social mood are its optimistic and pessimistic contents. Optimism and pessimism are the two opposing ways of perceiving the world, two opposing worldviews, the first of which is imbued with the joy of living, faith in the future and success, the tendency to see the good in everything; the second is related to the perception of the world imbued with despondency, hopelessness, lack of faith in a better future, a tendency to see bad in everything. Optimism and pessimism are "not just a state of mind of an individual, they

Table 1. Intentions represented in the social mood of the youth of Krasnoyarsk city

\begin{tabular}{|c|l|c|}
\hline & & \multicolumn{1}{|c|}{ Intention } \\
\hline 1. & To have an active life, to act & 11.7 \\
\hline 2. & To consume & 8.7 \\
\hline 3. & To have a passive life, to accept & 7.6 \\
\hline 4. & To destroy, to suppress & 7.3 \\
\hline 5. & To be selfish & 5.9 \\
\hline 6. & To take risks & 5.8 \\
\hline 7. & To control, to hold power & 5.3 \\
\hline
\end{tabular}


represent a different practical focus in the world, (...) personal attitudes, dispositions or opinions, moods reflecting positive or negative expectations about specific events or the future in general" (Muzdybaev, 2003).

To determine how extensively optimism and pessimism are represented in the mass consciousness (unconsciousness) of the youth of Krasnoyarsk city, we have applied the dispositional optimism test or the Life Orientation Test, which is a questionnaire intended for assessing optimism as a personal trait. The questionnaire was developed in 1985 by Charles Carver and Michael Scheier (Scheier et al., 1994; 1063), and validated in the Russian language sampling in 2003 by K. Muzdybaev, in 2012 by ordeeva, ychev and sin, in 2013 by siring and K.Iu. Evnina (Sychev, 2008).

A key feature of dispositional optimism test is that it studies generalized expectations manifested in the willingness to respond to any situation in a certain way. certain readiness to respond to any situation.

In our research we used the version of the test by Gordeeva-Sychev-Osin (Sychev, 2008). Therefore, the results of the optimism test obtained in the sampling of the youth of Krasnoyarsk city determine that dispositional optimism of this socio-demographic group significantly prevails over pessimism.

For the analysis of the sociological survey data representing this test, the corresponding keys were used. For each of the ten proposed judgments, the "yes" answer was awarded 4 points, "rather yes" was awarded 3 point, "neutral" was awarded 2 points, "rather not" was awarded 1 point and the "no" answer was given 0 points. Thus, we calculated the indicators characterizing the dispositional optimism-pessimism of each of the respondents:

- Optimism (O): 1, 4, 10 (minimum - 0, maximum - 12).

- Pessimism (P): 3, 7, 9 (minimum - 0, maximum - 12).

Distribution of responses of respondents to the questions forming the optimism chart is given in Fig. 1.

Distribution of responses of respondents to the questions forming the pessimism chart is given in Fig. 2.

The data presented in these figures show that the representatives of the young people in Krasnoyarsk much more often agree with the positions that are optimistic than the pessimistic

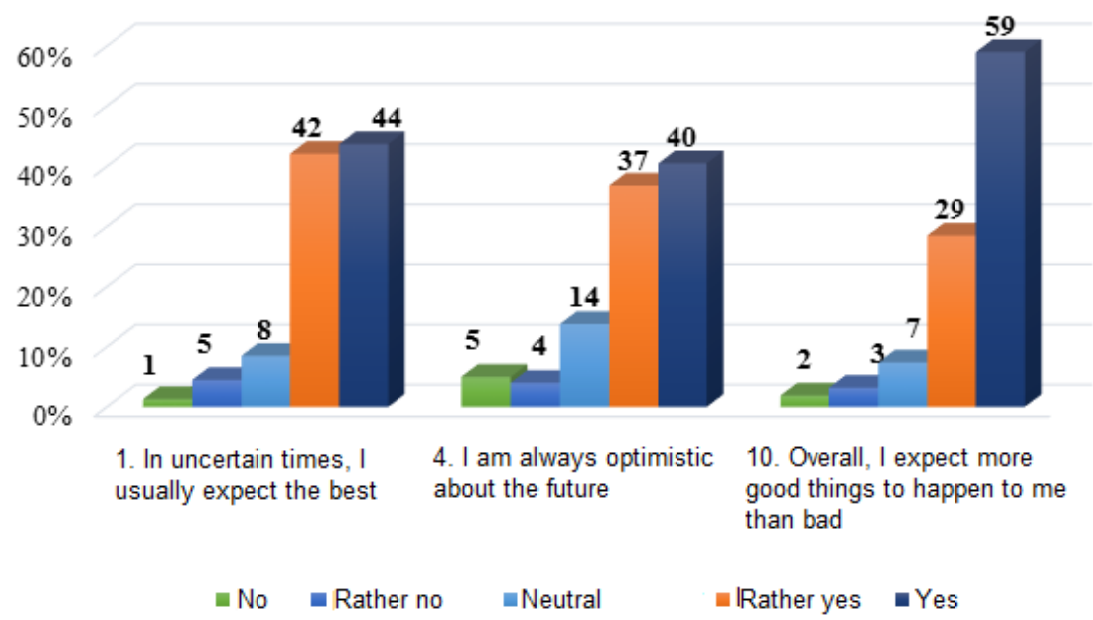

Fig. 1. Distribution of responses of the respondents to the questions forming the optimism chart, $\%$ 


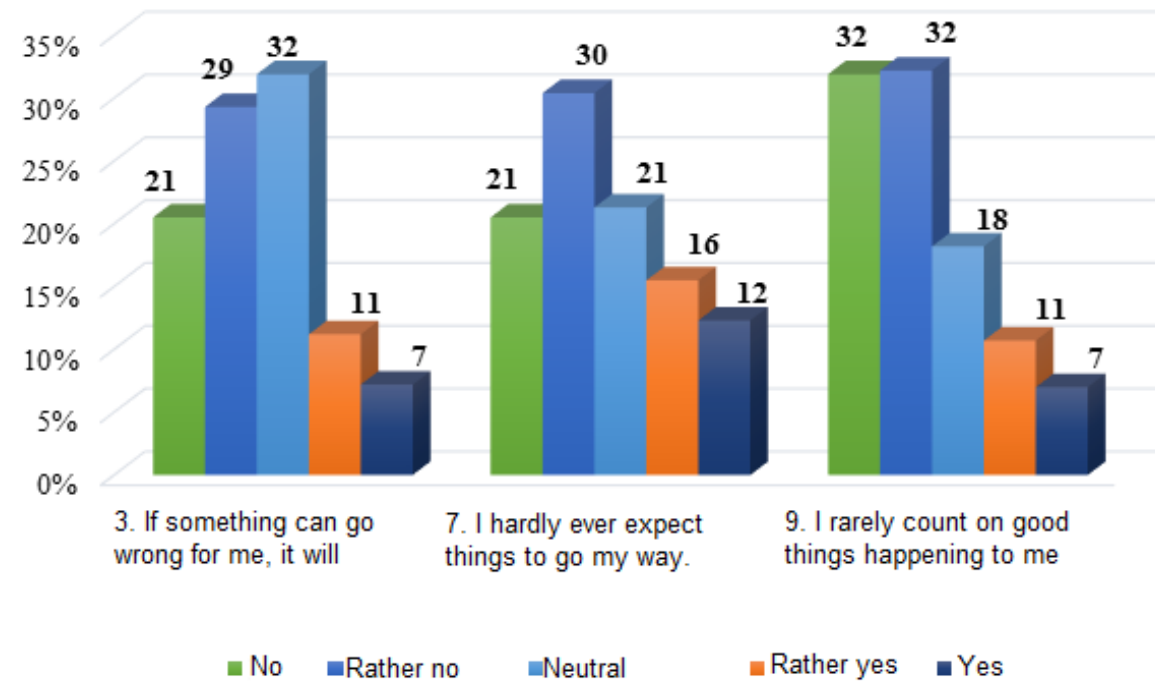

Fig. 2. Distribution of responses of the respondents to the questions forming the pessimism chart, $\%$

ones. Thus, in uncertain times, $86 \%$ of respondents tend to hope for the best, $77 \%$ are optimistic about the future ("yes" and "rather yes" answers). Finally, $88 \%$ of respondents said that overall they expected more good thing happen to them than bad.

According to the results of the test, sample multitude of representatives of the Krasnoyarsk youth has been divided into two categories: optimists and pessimists. For example, the respondents who turned out to have the "O" indicator (optimism) prevailing over the "P" indicator (pessimistic), were given a special value " 1 , an optimist" in a special variable. In contrast, the respondents with prevailing "P" indicator over the "O" indicator were given the value " 2 , pessimist" in a special variable. Thus, we can conclude that the proportion of pessimists in the sample multitude was $12 \%$, whilst the proportion of optimists was $85 \%$. The rest of the respondents - the so-called realists - had equal "O" and "P" indicators. The share of such respondents in the sample multitude was $4 \%$, but in this case this information is insignificant, since the main objective of the application of the test for dispositional optimism in the present study was to determine the distribution of the representatives of the Krasnoyarsk youth around two polar types of world perception, such as optimism and pessimism.

The above ratio is not accidental. It is enough to compare the results of the above optimism test with the results of statistical analysis of the responses to the questions of the sociological surveys where the respondents were asked to assess the quality of the changes in their lives over the past year and suggest the quality of changes in their lives expected in the coming year. $73 \%$ of the respondents to varying degrees were optimistic regarding the quality of changes in their lives over the past year, while $83 \%$ expected their life to improve in the coming year.

It is clear that the evidence of general optimism and pessimism level, established with the presented methods, is not sufficient for studies of the social mood of this or that social subject. As social mood is a dynamic system and as the basis for the behavior of a social subject is its needs, social mood studies require collecting 
information on the needs underlying the activity of the studied subject.

There are three hierarchic levels formed by the developing system: the tangible-energetic, functional-organizational and informational. Being an emotional and rational characteristic of a social system, social mood reveals these levels in correspondence with the L. Kohlberg's three levels of moral development as it develops (Trufanov, 2006; Kohlberg, 1984; 172-181).

On the tangible-energetic level, the social mood presents itself as dependent on the economic component and psychophysiological elements associated with the most primitive individual world perception processes (sense, emotions connected with security, a sense of fullness and health). The social mood of this level is mostly connected with the subject's commitment to the personal physiological existence issues and, therefore, is characterized with the most distinctive emotional attitude to the actualization level of the appropriate need type.

The social mood of the functionalorganizational level is connected to the social aspect of individual existence, where the social experience, mindset and worldview, forming in the process of social interaction, come to the fore. The mood of this level manifests itself predominantly in the commitment to the group or individual behavior determined by the values of the groups and other people. The social mood of this level is associated with the brightest evaluation of the emotional attitude to the social needs' actualization level.

As for the social mood of the informational level, here the states of consciousness and behavior associated with the subject's selfactualization, reflected in the unique attitude to the world and spiritual aspirations, come to the fore. On this level, it is appropriate to speak of such components of consciousness as will, imagination and inspiration. The content of the social mood on the informational level is based on the strong autonomy of an individual from the human associations, their norms and standards: positive and negative emotions caused by selffulfillment are reflected in the most distinctive way.

It is clear that the levels listed above are perfect types, and distinction of the three levels in the social mood structure is conventional. At the same time, it seems impossible to measure the specific weight of each level in the studied subject's social mood by any empirical means. Nevertheless, the correlation and the factor analysis of the research results allows to conclude that it is rational to speak at least of three social mood levels, and, if any certain level dominates in this or that social community, of the three types of it.

To determine the main components in the composition of the social mood of the modern youth of Krasnoyarsk, we performed the factor analysis of the answers to the following question: "Imagine yourself in ten years' time. What features do you think will be typical for your life?" This method was developed by emirovsky 20 years back and proved its efficiency in the multiple researches where it was used (Nemirovsky \& Nevirko, 269-282). This question demonstrates the link between the social mood subject's idea of his own present and future, which is essential in the social mood studies. Thus, it is fair to state that one cannot judge of the quality of his future life without consideration of the current situation in the main spheres of his life, or disregarding it completely. The value of the discussed question in the social mood research is that the respondent supposes what his future life may be like on the basis of his previous experience, the current situation and with respect to his intentions and aspirations. Therefore, it touches upon both the objective and subjective sides of the question. The results 
of the factor analysis using the Varimax rotation method are presented in Table 2 .

4. Discussion. Therefore, there is a foundation to outline three types of social mood: prestige-consumerist, or selfish; creative, or demiurgic; and spiritual, or altruistic. Let us take a closer look at each of them.

The first type of social mood is the prestigeconsumerist. The representativeness of the factor that corresponds to this social mood type for the totality of Krasnoyarsk citizens aged from 14 to 30 is $26 \%$. The correlation analysis demonstrated that the intentions related to this social mood type are: "to control", "to be selfish", "to act" and "to consume". The respondents demonstrating this social mood type selected the following answers to the question "How do you like to spend your free time?": "to meet friends", "to do social activities", "to go to night clubs, discos, bars, restaurants, cafes", while such option as "to read books, newspapers, magazines" was less preferred. Moreover, the prestige-consumerist social mood type individuals would characterize themselves as outstanding, unique, self-confident and energetic more frequently than others. This mood type is associated with pleasure, entertainment and excitement as the aspects describing interaction of the social mood subject with the surrounding world. This is the most optimistic social mood type of the three.

The second social mood type is the creative one. The representativeness of the factor correlated with this type is $16 \%$. This social mood type corresponds to the intention for risk and action, and at the same time, this type denies such intents as "to destroy" and "to conform". The young people of Krasnoyarsk demonstrating this social mood type answered the question about their favorite past-time as follows: "to read books, newspapers, magazines", "to visit museums, exhibitions", "to attend various courses, develop professionalism", "to go to

Table 2. Rotated component matrix (based on the factor analysis of the answers given to the question: "Imagine yourself in ten years' time. What features do you think will be typical for your life?")

\begin{tabular}{|l|c|c|c|}
\hline & $\begin{array}{c}\text { Factor 1 } \\
(26 \%) \\
\text { Prestige-consumerist } \\
\text { (selfish) }\end{array}$ & $\begin{array}{c}\text { Factor 2 } \\
(16 \%) \\
\text { Creative (demiurgic) }\end{array}$ & $\begin{array}{c}\text { Factor 3 } \\
\text { Spiritual (altruistic) }\end{array}$ \\
\hline 2. Material wealth & 0,786 & & \\
\hline $\begin{array}{l}\text { 5. Good opportunities for entertainment and } \\
\text { recreation }\end{array}$ & 0,745 & & \\
\hline 7. Superior position & 0,713 & & 0,35 \\
\hline 4. Prestige, admiration of the peers & 0,64 & & \\
\hline 6. Good family & 0,61 & 0,34 & 0,83 \\
\hline $\begin{array}{l}\text { 8. Interesting creative job } \\
\text { 9. Regular reading, attendance of theatres and } \\
\text { "serious music" concerts }\end{array}$ & 0,5 & 0,79 & \\
\hline $\begin{array}{l}\text { 11. Spiritual development, moral self- } \\
\text { improvement }\end{array}$ & & & \\
\hline 1. Active sports trainings & & & \\
\hline 3. Faith in god & & & 0,4 \\
\hline $\begin{array}{l}\text { 10. Life for people, despite the profession and } \\
\text { the position, sometimes against one's own } \\
\text { interests }\end{array}$ & & & \\
\hline
\end{tabular}


theatres, cinemas, concerts", and "to do sports, to go in for dancing". It is worth noticing that such past-times as watching $\mathrm{TV}$, listening to radio, simple relaxation are not typical of them. This social mood type is characterized with the commitment to the spiritual opposed to the material, and to unique opposed to routine.

The third social mood type is altruistic (the representativeness of the correlating factor is $13 \%$ ). This type denies the intention "to be selfish". Going to the church, doing the house chores and spending time with children are the most acceptable types of leisure for the respondents who can be classified as the bearers of such social mood. Love, altruism and anxiety are the three categories that describe the interaction of the altruistic social mood subjects with the world. Vigour and selflessness are the main qualities of the people demonstrating this social mood type.

5. Conclusion. So, the social mood of the modern youth of Krasnoyarsk, studied as an integral structural and dynamic characteristic, was considered in the present article as a dominant form of consciousness and the unconscious of the studied socio-demographic group at the present moment, based on the way of emotional and rational perception of the social reality by this group also actualized in their practical activities.

Due to the sophistication and complexity of the social mood phenomenon and, consequently, the high information value of the research dedicated to it, the social mood of the modern youth of Krasnoyarsk was studied through the prism of the diatropic principle of the minimal universum that acts as a matrix that suggests that the phenomenon should be studied in its integrity. So, the present principle enabled us to look through the structural and dynamic components of the social mood of the modern Krasnoyarsk youth from inside, which is based at least on the following logical reasons:

1. General emotional connotation of the social mood or dispositional optimism (Scheier and Carver's dispositional optimism test);

2. The level of the value commitments composing the base for the social mood;

3. The focus of the social mood on the emotional sufferings of this or that type (the "Emotional focus of a personality" questionnaire by Nemirovsky V.G.) (Nemirovsky, 2004).

The minimal universum of the social mood of the modern Krasnoyarsk youth is shown in Table 3.

So, the research results prove that the social mood of the modern Krasnoyarsk youth can be characterized as mostly optimistic with the domination of functional-organizational level features, where it [the mood] is mostly committed to experience positive emotions connected, first of all, with the satisfaction of the need to socialize. It is not a coincidence that the majority (69 \%) of the respondents said that they preferred to meet their friends in their free time. Moreover,

Table 3. The minimal universum of the social mood of the modern youth of Krasnoyarsk

\begin{tabular}{|c|c|c|c|}
\hline \multicolumn{2}{|c|}{$\begin{array}{l}\text { System: } \\
\text { Social mood (student youth of the city of } \\
\text { Krasnoyarsk) }\end{array}$} & \multirow{2}{*}{$\begin{array}{l}\text { Levels: } \\
\text { Prestige-consumerist, selfish } \\
(26 \%) \\
\text { Creative, demiurgic } \\
(16 \%) \\
\text { Spiritual, altruistic }(13 \%)\end{array}$} & \multirow{2}{*}{$\begin{array}{l}\text { Intention layers: } \\
\text { have an active life, act }(12 \%) \\
\text { consume }(9 \%) \\
\text { have a passive life, accept }(8 \%) \\
\text { destroy, suppress }(7 \%) \\
\text { be selfish }(6 \%) \\
\text { take risks }(6 \%) \\
\text { control, hold power }(5 \%)\end{array}$} \\
\hline $\begin{array}{l}\text { Element 1: } \\
\text { Optimism }(85 \%)\end{array}$ & $\begin{array}{l}\text { Element 2: } \\
\text { Pessimism }(12 \%)\end{array}$ & & \\
\hline
\end{tabular}


the commitments to the value experience corresponding to the functional-organizational level needs occupy the first ranks in the rating. These are the needs to socialize (97\%), to assist others (97\%), to act (96\%), to have love affairs (95\%). Therefore, the modern Krasnoyarsk youth demonstrates the social level mood corresponding to the functional-organizational level of the values and needs' system. At the same time, the commitment to such basic experience of tangibleenergetic level as security, enjoying delicious food, relaxation and peaceful life also bear a great significance in the collective consciousness of the modern youth.

The opinions on the last year's changes expressed by Krasnoyarsk citizens aged from 14 to 30 are mostly positive, both in respect with the ideas of their own lives, and with their idea of life in Krasnoyarsk as a whole. It is worth noticing that their idea of changes in the respondents' lives is more optimistic than that of the changes in the city life. If the changes that occurred in their private life within the past year were more or less positively assessed by $73 \%$ of the respondents, the changes that occurred in the city life were positively evaluated only by $37 \%$ of them. Over $40 \%$ of the respondents claimed that the changes in the city life did not occur at all.

We observe a similar situation in the young people's ideas of the future. If any positive changes in the personal life are expected in the next year by the absolute majority of the respondents ( $83 \%$ ), only a half of them expect such changes in the life of the city (54\%). Almost $35 \%$ assume that the city life would not change in the next year. Thus, the mood of the Krasnoyarsk youth concerning the changes in the city life, is more reserved and conservative than that connected with the changes expected in their own lives. It can be best explained by the fact that young people feel more responsibility for the quality of changes happening in their personal life than for the quality of changes in the city life.

First of all, the youth of Krasnoyarsk demonstrates the aspiration for such values as a good family, material wealth, and good opportunities for recreation and entertainment, along with the spiritual development and selfimprovement. Over $90 \%$ of the respondents believe that such features will "probably" or "definitely" be present in their lives in ten years' time.

Summarizing everything said above, we may conclude that the social mood of the modern Krasnoyarsk youth can be characterized as a social mood of the mixed, transitional type, with the domination of the functional-organizational level features, where it [the mood] is mostly oriented on experiencing positive emotions coming from professional success and relationships with other people. However, the commitment to such basic experience of the tangible-energetic level as safety, enjoying good meals, relaxation and peaceful life, also have great relevance in the collective consciousness (unconscious) of the youth. In general, the social mood of the Krasnoyarsk youth is more optimistic than pessimistic. However, returning to the postulate on the practical meaning of studying the social mood, that does not only reflect the past experience of a certain social collective, but also determines the actual behavior of its representatives, it should be noted that the satisfaction with some aspects of life (environmental situation, material status, economic, social situation and safety of the city) remains low. Such data can serve as a basis for the development of a social process management strategy. We should not forget that the well-being of a society is also determined by the pragmatist potential of its members, which still remains relatively low.

The monitoring research of the social mood of various social groups can be used to trace 
its dynamics. The data obtained as a result of integrated studies of the social mood of the youth can be applied to develop or correct some youth policy programs (in the present case, the youth policy programs of the city of Krasnoyarsk). The universum sociology approach acts as a universal matrix, a fundamental methodological base that provides new opportunities for the objective comparison of the social moods of various groups or the moods demonstrated by the same group within several different time periods. It can also be used to systematize the approaches to understanding the social mood phenomenon existing in modern sociology and to come up with a new concept of the phenomenon that would not contradict to all the previously existing ones. The objective social mood picture helps to predict the behavior of the studied social or socio-demographic group as well as to consider the possible risks. The ratio of indices characterizing the social mood of the population with such index as life quality also bears great significance. The studies of the mentioned two phenomena together paints a complete picture of the certain region's population's life.

\section{References}

Balatskii, E. V. (2005). Methods of diagnosis of social well-being of the population [Metody diagnostiki sotsial'nogo samochuvstviia naseleniia]. Monitoring of public opinion: economic and social change, (3), 47-53.

Golovakha, E. I. \& Panina, N. V. (2005). The integral index of social well-being of the population of Ukraine before and after the "orange revolution" [Integral'nyi indeks sotsial'nogo samochuvstviia naseleniia Ukrainy do i posle" oranzhevoi revoliutsii”]. Herald Opinion: Data. Anal. Discussions, 6 (80), 11-16.

Khasbulatova, O. A. \&Egorova, L. S. (2002). Social well-being of women and men in secondary cities in Russia [Sotsial'noe samochuvstvie zhenshchin i muzhchin v srednikh gorodakh Rossii]. Sociological research, (11), 48-54.

Kohlberg, L. Essays on moral development. Vol. 2. The psychology of moral development, 1984.

Lepeshkin, N. IA. Sotsial'noe samochuvstvie naseleniia na sovremennom etape transformatsii rossiiskogo obshchestva: regional'nyi aspekt [Social well-being of the population at the present stage of transformation of the Russian society: regional aspect]. Khabarovsk, 2004. 168 p.

Muzdybaev, K. (2003). Optimism and pessimism of the person (experience of sociological and psychological research [Optimizm i pessimizm lichnosti (opyt sotsiologo-psikhologicheskogo issledovaniia]. Sociological research, (12), 87-96.

Nemirovsky, azovye tsennosti $v$ massovom soznanii: tsennostnye perezhivaniia, smysl zhizni $i$ otnoshenie $k$ smerti, grekh kak sotsial'nyi fenomen: Kurs lektsii [The basic values of the mass consciousness: the value of experience, the meaning of life and attitude to death, sin, as a social phenomenon: Lectures]. Krasnoyarsk, Krasnoyarsk State University, 2002.

Nemirovsky, bshchaia sotsiologiia [General sociology]. Rostov n/D, Feniks, 2004, $314 \mathrm{p}$.

Nemirovsky, V. G. (2004). Universumnaia paradigma sovremennoi rossiiskoi sotsiologii kak perspektiva razvitiia [Universe paradigm of modern Russian sociology as a perspective of development]. Sotsiologiia (Social science), (1), 39-49. 
Nemirovsky, V. G. \& Nevirko, otsiologiia cheloveka: ot klassicheskikh k postneklassicheskim podkhodam [Sociology person: from classical to post non-classical approaches]. Moscow, LKI, 2008, $194 \mathrm{p}$.

Nemirovsky, V. G. \& Nemirovskaia, A. V. (2015). Sotsial'naia struktura i sotsial'nyi kapital naseleniia Krasnoiarskogo kraia [The social structure and the social capital of the population of the Krasnoyarsk Territory]. Krasnoyarsk, Siberian Federal University, 2015, 158 p.

Nemirovsky, V. G. \& Starikov, P. A. (2003). The trend of "quasi-religious" among Krasnoyarsk students [Tendentsiia" kvazireligioznosti" v srede krasnoiarskogo studenchestva]. Sociological research, (10), 96-101.

Orlov, ovedencheskie refleksii sel'skogo naseleniia v usloviiakh agrarnykh preobrazovanii: determinanty, tipologii, tendentsii [Behavioral reflection of the rural population in the conditions of agrarian reform: determinants, typologies and trends]. Moscow, Moscow State University, 2000.

Petrova, L. E. (2000). Social well-being of young people [Sotsial'noe samochuvstvie molodezhi]. Sociological research, (12), 50-55.

Rogozin, D. O. (2007). Testing issues about the social well-being [Testirovanie voprosov o sotsial'nom samochuvstvii]. Social Reality, (2), 97-113.

Rubina, L. IA. (1996). Professional and social well-being of teachers [Professional'noe i sotsial'noe samochuvstvie uchitelei]. Sociological research, (6), 63-75.

Rusalinova, A. A. (1994). Social well-being in today's world as a scientific problem [Sotsial'noe samochuvstvie cheloveka $\mathrm{v}$ sovremennom mire kak nauchnaia problema]. Vestnik SPbGU (St. Petersburg State University Gazette), 6(1), 49-60.

Scheier, M. F., Carver, C. S. \& Bridges, M. W. (1994). Distinguishing optimism from neuroticism (and trait anxiety, self-mastery, and self-esteem): a reevaluation of the Life Orientation Test. Journal of personality and social psychology, 67(6), 1063.

Sheregi, F. E. \& Kharcheva, V. G. (1996). Social problems of university science [Sotsial'nye problemy vuzovskoi nauki]. Sociological research, (6), 76-81.

Simonovich, N. E., Kol'tsova, V. A. \& Oleinik Iu. N. Social well-being: psychological interpretation [Sotsial'noe samochuvstvie cheloveka: psikhologicheskaia interpretatsiia]. Tezisy dokladov k mezhdunarodnoi nauchno-prakticheskoi konferentsii Individual'nyi i gruppovoi sub"ekty $v$ izmeniaiushchemsia obshchestve: $k$ 110-letiiu so dnia rozhdeniia ubinshteina (Abstracts of the international scientific-practical conference Individual and group entities in a Changing Society: to the 110th anniversary of the birth of SL Rubinstein). Moscow, 1999, pp. 88-89.

Stepanova, otsial'noe samochuvstvie kak faktor migratsionnogo povedeniia naseleniia Kamchatskogo kraia [Social well-being as a factor in the migration behavior of the population of Kamchatka Territory]. Khabarovsk, 2013.

Sychev, sikhologiia optimizma: uchebno-metodicheskoe posobie k spetskursu [Psychology of optimism: a teaching guide for the course]. Biisk, BPGU them. hukshin, 2008.

Toshchenko, ZH. T. \& Kharchenko, ocial mood. Moskow, Academia, 1996, 196 p.

Toshchenko, ZH. T. (1998). Social mood, a phenomenon of modern sociological theory and practice [Sotsial'noe nastroenie - fenomen sovremennoi sotsiologicheskoi teorii i praktiki]. Sociological research, (1), 21-34. 
Trufanov, sennostnaia sotsiologicheskaia kontseptsiia sovremennykh edinoborstv [Valuable sociological concept of modern martial arts]. Krasnoyarsk, Krasnoyarsk State University, 2006.

Zborovskii, G. E. \& Shirokova, E. A. (2001). Social nostalgia: the study of the phenomenon [Sotsial'naia nostal'giia: k issledovaniiu fenomena]. Sociological research, (8), 31-34.

\section{Интегративный подход к изучению феномена социального настроения \\ с позиции универсумной социологии \\ (на примере социального настроения молодёжи города Красноярска)}

О.В. Васильева

Сибирский федеральный университет Россия, 660041, Красноярск, пр. Свободный, 79

В статье с точки зрения универсумной социологии рассматривается сочиальное настроение как многоаспектная характеристика социальной общности, формирующаяся под воздействием социильной практики и во многом определяющая социальное поведение представителей данной общности. Феномен социального настроения рассматривается в его иелостности как развивающаяся динамическая система, обладающая многоуровневой структурой; высказывается позиция автора относительно соотношения понятий социильного настроения и социального самочувствия; определяется представленность оптимизма и пессимизма в массовом сознании (бессознательном) молодёжи города Красноярска, выделяются три основных типа социального настроения, определяются основные типь интенций, характерных для социального настроения данной социальнодемографической группьл.

Ключевые слова: социальное настроение, сочиальное самочувствие, молодёжь, принцип минимального универсума, оптимизм, пессимизм, потребности, направленность на эмоциональные переживания.

Научная специальность: 22.00.00 - сочиологические науки. 